Marquette University

e-Publications@Marquette

$1-1-2005$

Scope and Mechanistic Study of the RutheniumCatalyzed ortho-C-H Bond Activation and Cyclization Reactions of Arylamines with Terminal Alkynes

Chae S. Yi

Marquette University, chae.yi@marquette.edu

Young Yun

Marquette University

Accepted version. Journal of the American Chemical Society, Vol. 127, No. 48 (2005): 17000-17006.

DOI. (C) 2005 American Chemical Society. Used with permission. 


\title{
Scope and Mechanistic Study of the Ruthenium-Catalyzed ortho-C-H Bond Activation and Cyclization Reactions of Arylamines with Terminal Alkynes
}

\author{
Chae S. Yi \\ Department of Chemistry, Marquette University, \\ Milwaukee, WI \\ Sang Young Yun \\ Department of Chemistry, Marquette University, \\ Milwaukee, WI
}

\section{Abstract}

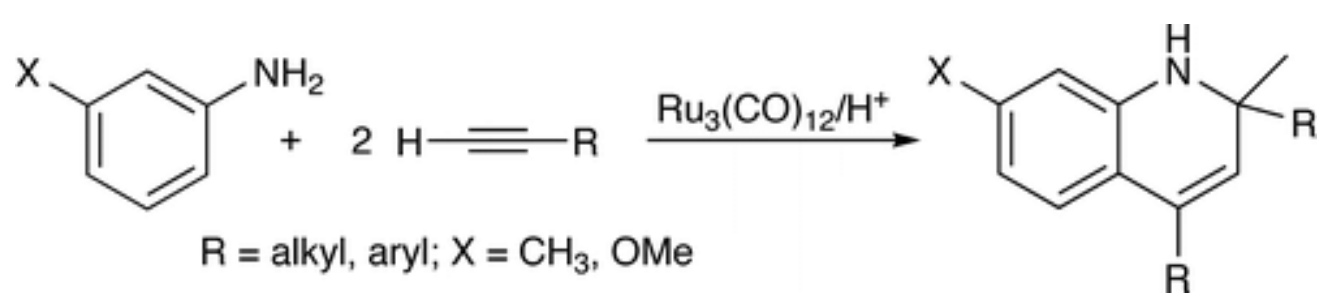


The cationic ruthenium hydride complex $\left[\left(\mathrm{PCy}_{3}\right)_{2}(\mathrm{CO})\left(\mathrm{CH}_{3} \mathrm{CN}\right)_{2} \mathrm{RuH}^{+} \mathrm{BF}_{4}^{-}\right.$was found to be a highly effective catalyst for the $\mathrm{C}-\mathrm{H}$ bond activation reaction of arylamines and terminal alkynes. The regioselective catalytic synthesis of substituted quinoline and quinoxaline derivatives was achieved from the ortho- $\mathrm{C}-\mathrm{H}$ bond activation reaction of arylamines and terminal alkynes by using the catalyst $\mathrm{Ru}_{3}(\mathrm{CO})_{12} / \mathrm{HBF}_{4} \cdot \mathrm{OEt}_{2}$. The normal isotope effect $\left(k_{\mathrm{CH}} / k_{\mathrm{CD}}=\right.$ 2.5) was observed for the reaction of $\mathrm{C}_{6} \mathrm{H}_{5} \mathrm{NH}_{2}$ and $\mathrm{C}_{6} \mathrm{D}_{5} \mathrm{NH}_{2}$ with propyne. $A$ highly negative Hammett value $(\rho=-4.4)$ was obtained from the correlation of the relative rates from a series of meta-substituted anilines, $m-\mathrm{XC}_{6} \mathrm{H}_{4} \mathrm{NH}_{2}$, with $\sigma_{\mathrm{p}}$ in the presence of $\mathrm{Ru}_{3}(\mathrm{CO})_{12} / \mathrm{HBF}_{4}$. OEt 2 (3 mol \% Ru, 1:3 molar ratio). The deuterium labeling studies from the reactions of both indoline and acyclic arylamines with DC:CPh showed that the alkyne $\mathrm{C}-\mathrm{H}$ bond activation step is reversible. The crossover experiment from the reaction of 1-(2-amino-1phenyl)pyrrole with $\mathrm{DC}: \mathrm{CPh}$ and $\mathrm{HC}: \mathrm{CC}_{6} \mathrm{H}_{4}-p-\mathrm{OMe}$ led to preferential deuterium incorporation to the phenyl-substituted quinoline product. A mechanism involving rate-determining ortho- $\mathrm{C}-\mathrm{H}$ bond activation and intramolecular $\mathrm{C}-\mathrm{N}$ bond formation steps via an unsaturated cationic ruthenium acetylide complex has been proposed.

\section{Introduction}

Considerable research has been directed to the development of catalytic $\mathrm{C}-\mathrm{H}$ bond activation methods which are applicable to the synthesis of biologically important quinolines, indoles, and related nitrogen heterocyclic compounds. ${ }^{1}$ In part due to their innate ability for functional group tolerance, late-transition-metal catalysts have been found to be suitable for directing regio- and chemoselective $\mathrm{C}-\mathrm{H}$ bond activation reactions of nitrogen compounds. For example, Rh and $\mathrm{Ir}$ catalysts have been successfully utilized for highly regioselective $\mathrm{sp}^{2}$ $\mathrm{C}-\mathrm{H}$ bond activation reactions of benzimidazole and related nitrogen heterocyclic compounds ${ }^{2}$ and $\mathrm{sp}^{3} \mathrm{C}-\mathrm{H}$ bond insertion reactions of amine compounds. ${ }^{3}$ Chelation control methodology has been shown to be particularly effective for mediating regioselective $\mathrm{C}-\mathrm{H}$ bond activation reactions of nitrogen compounds, ${ }^{4}$ and has recently been utilized for the synthesis of pharmaceutically important polycyclic alkaloids. ${ }^{5}$ Both intermolecular ${ }^{6}$ and intramolecular ${ }^{7}$ oxidative $\mathrm{C}-\mathrm{H}$ bond activation reactions of indole and pyridine derivatives have recently been achieved by using $\mathrm{Pd}, \mathrm{Pt}$, and $\mathrm{Cu}$ catalysts. A remarkably selective catalytic $\mathrm{sp}^{3} \mathrm{C}-\mathrm{H}$ bond oxidative amination method has been successfully applied to the synthesis of amino acid derivatives. ${ }^{8}$

Inspired by recent reports on the unusual reactivity of latemetal amido complexes, ${ }^{9}$ we have begun to explore the catalytic 
activity of well-defined ruthenium amido complexes for $\mathrm{N}-\mathrm{H}$ and other unreactive bond activation reactions. ${ }^{10}$ We recently discovered that the cationic ruthenium hydride complexes are highly effective catalysts for the regioselective intermolecular $\mathrm{C}-\mathrm{H}$ bond activation reaction of benzocyclic amines with terminal alkynes. ${ }^{11}$ The catalytic method efficiently produces tricyclic quinoline derivatives from the direct coupling of unprotected amines and terminal alkynes without chelatedirecting groups. In this paper we delineate the scope and mechanistic study of the ruthenium-catalyzed $\mathrm{C}-\mathrm{H}$ bond activation and cyclization reactions of arylamines and terminal alkynes.

\section{Results and Discussion}

Reaction Scope. While studying the ruthenium-catalyzed hydroamination and other $\mathrm{C}-\mathrm{C}$ bond forming reactions, we initially discovered that the cationic ruthenium hydride complex $\left[\left(\mathrm{PCy}_{3}\right)_{2}(\mathrm{CO})\left(\mathrm{CH}_{3} \mathrm{CN}\right)_{2} \mathrm{RuH}^{+} \mathrm{BF}_{4}^{-}(\mathbf{1})\right.$ is an effective catalyst for the coupling reaction of benzocyclic amines and terminal alkynes (eq 1). ${ }^{11}$ For example, the treatment of indoline (30 $\mathrm{mg}, 0.25 \mathrm{mmol}$ ) with excess propyne (20 equiv) in the presence of 1 ( $5 \mathrm{~mol} \%$ ) in benzene at $95{ }^{\circ} \mathrm{C}$ for $24 \mathrm{~h}$ cleanly produced the tricyclic products $\mathbf{2 a}$ and $\mathbf{3 a}$ $(15: 1)$ in $81 \%$ combined yield (eq 1 ).

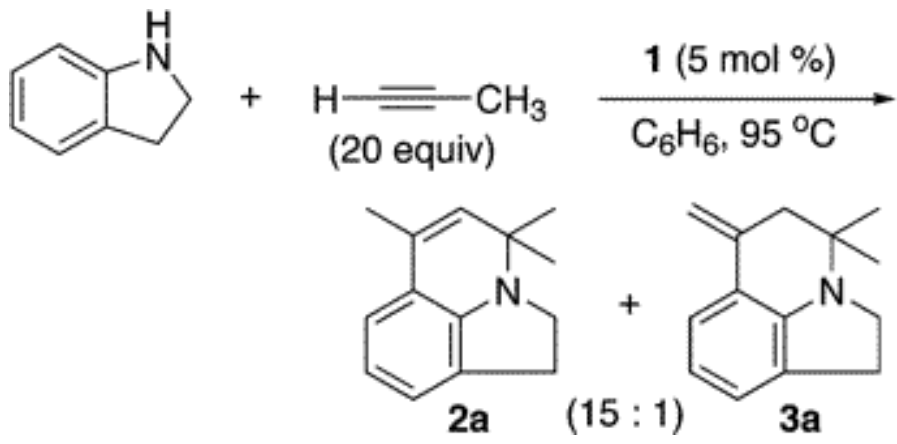

Since complex 1 was found to be less effective for electrondeficient terminal alkynes, the activity of commonly available ruthenium catalysts and additives was surveyed to find a suitable catalytic system. The complex $\mathrm{Ru}_{3}(\mathrm{CO})_{12}$ (4) with an additive, $\mathrm{NH}_{4} \mathrm{PF}_{6}$ or $\mathrm{HBF}_{4} \cdot \mathrm{OEt}_{2}$, was found to be the most effective catalyst for the coupling reaction of amines and alkynes. ${ }^{12}$ For example, $1 \mathrm{~mol} \%$ $\mathbf{4} / \mathrm{NH}_{4} \mathrm{PF}_{6}$ (1:3 molar ratio) gave a nearly quantitative yield of $\mathbf{2 a}$ and 
$3 a(20: 1,99 \%$ combined yield) in less than $12 \mathrm{~h}$ for the reaction of indoline with propyne. Previously, the catalytic system

$\mathrm{Ru}_{3}(\mathrm{CO})_{12} / \mathrm{NH}_{4} \mathrm{PF}_{6}$ was utilized for the hydroamination and $\mathrm{C}-\mathrm{C}$ bond activation reactions. ${ }^{13}$

The reaction scope of benzocylic amines and alkynes was explored by using the catalytic system $4 / \mathrm{NH}_{4} \mathrm{PF}_{6}$. Both five- and sixmembered benzocyclic amines were found to readily undergo the regioselective coupling reaction with terminal alkynes to give the tricyclic products $\mathbf{2}$ and $\mathbf{3}$. In most cases, only trace amounts of the isomerization products $\mathbf{3}$ were formed. Both aliphatic and arylsubstituted terminal alkynes were found to be suitable substrates, but no coupling product was formed with sterically demanding terminal alkynes such as 3-methyl-1-butyne and internal alkynes. A detailed description of the catalytic reaction has recently been reported. ${ }^{11}$

In an effort to extend the scope, we next surveyed the catalytic coupling reactions of acyclic arylamines and terminal alkynes. Initially, the reaction of aniline $(50 \mathrm{mg}, 0.54 \mathrm{mmol})$ and excess propyne $(2.5$ $\mathrm{mmol}$ ) in the presence of $\mathbf{4} / \mathrm{HBF}_{4} \cdot \mathrm{OEt}_{2}(5 \mathrm{~mol} \% \mathbf{2}, 1: 3$ molar ratio) in benzene at $95{ }^{\circ} \mathrm{C}$ produced a $\sim 1: 1$ mixture of the ortho- $\mathrm{C}-\mathrm{H}$ bond activation product $\mathbf{5 a}$ and the hydroamination product $\mathbf{6 a}$ in ca. $80 \%$ combined yield (eq 2). A few optimization efforts such as increasing alkyne concentration or altering the ratio of catalyst to cocatalyst did not significantly improve the product yield of $\mathbf{5 a}$. The organic products were readily separated by column chromatography, and the structure was completely established by spectroscopic methods.
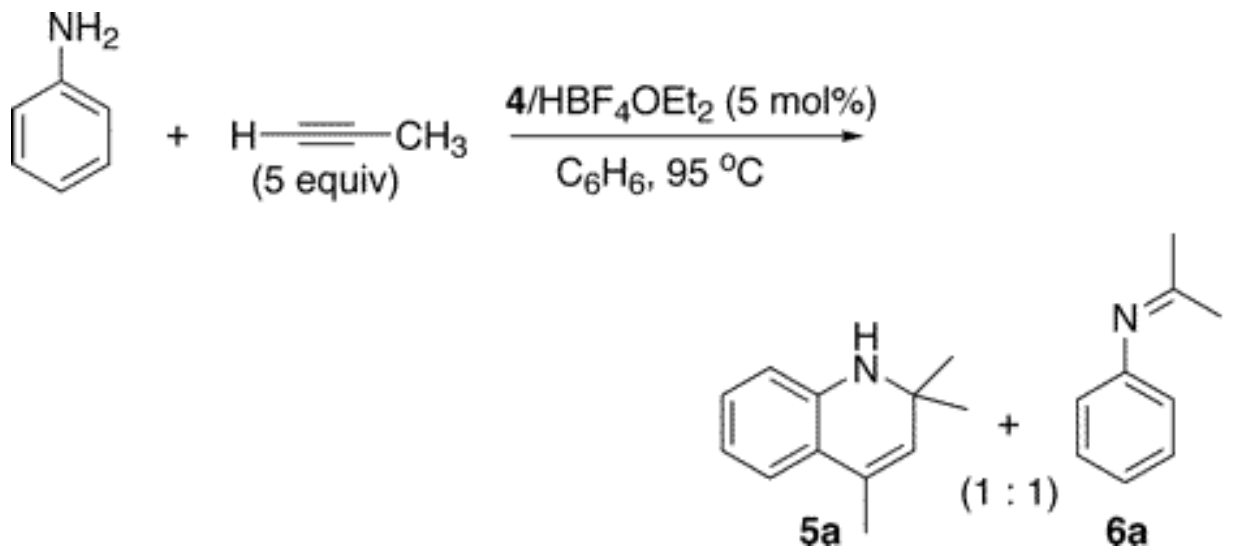
We reasoned that the ortho- $\mathrm{C}-\mathrm{H}$ bond activation would be strongly influenced by the meta-substituent of the arylamines. Indeed, a meta-electron-donating group was found to promote the ortho- $\mathrm{C}-\mathrm{H}$ bond activation of aniline to give the products $\mathbf{5}$ preferentially over the hydroamination products $\mathbf{6}$, in which cases less than $5 \%$ of $\mathbf{6}$ was formed in the crude reaction mixture (Table 1 , entries 2-6). Both alkyl- and aryl-substituted terminal alkynes were found to be suitable substrates for the secondary arylamine (entries 8-11). For 3,4disubstituted anilines, the coupling products $\mathbf{5} \mathbf{I}$ and $\mathbf{5 m}$ were formed from the regioselective ortho- $\mathrm{C}-\mathrm{H}$ bond activation para to the electron-donating group $\mathrm{R}^{\prime \prime}$ (entries 12 and 13). Similar regioselective ortho- $\mathrm{C}-\mathrm{H}$ bond activation was also observed for the functionalized bicyclic arylamines to give the tricyclic quinoline products $\mathbf{5 n - 5 q}$ (entries 14-17). In contrast, arylamines with an electron-withdrawing group (e.g., $m$-chloroaniline) formed $<5 \%$ of the $\mathrm{C}-\mathrm{H}$ bond activation product $\mathbf{5}$ under similar reaction conditions, giving mostly the hydroamination product ( $90 \%)$. A substituted hydroquinoline core structure is commonly present in a variety of natural products and pharmaceutical agents. ${ }^{14}$

Table 1. Coupling Reaction of Arylamines and Terminal Alkynes ${ }^{a}$

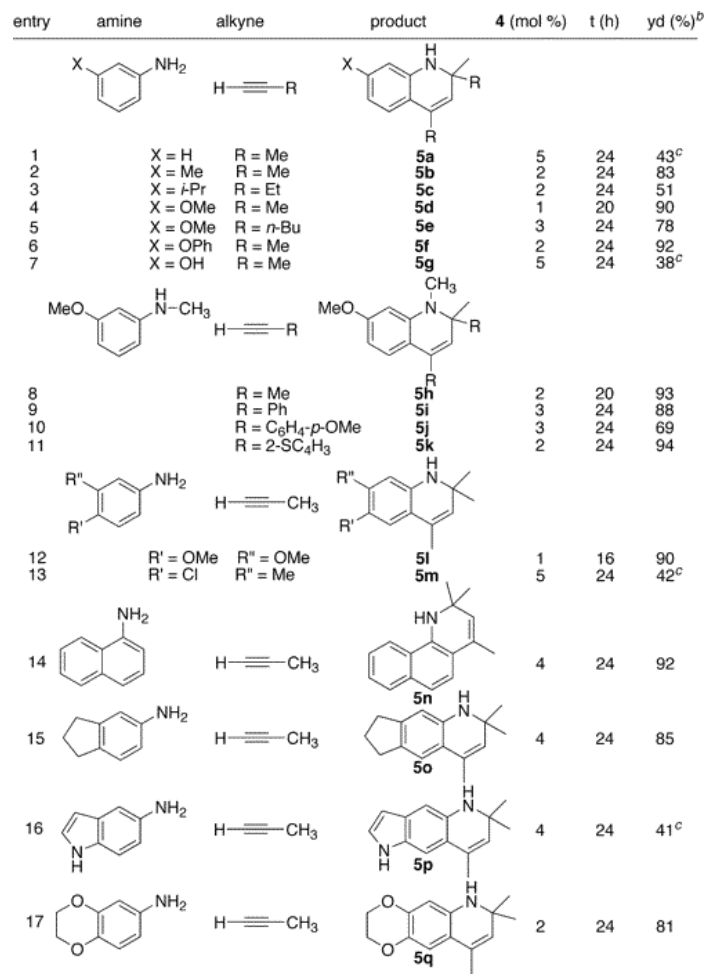


${ }^{a}$ Reaction conditions: amine $(1.5 \mathrm{mmol})$, alkyne $(5-10 \mathrm{mmol}), \mathrm{Ru}_{3}(\mathrm{CO})_{12} / \mathrm{HBF}_{4} \cdot \mathrm{OEt}_{2}$ (1:3), benzene $(2-5 \mathrm{~mL}), 90-100{ }^{\circ} \mathrm{C} .{ }^{b}$ Isolated yield based on amine. ${ }^{c} \mathrm{~A} 40-50 \%$ yield of 6 was formed.

The catalytic method was successfully extended to the synthesis of quinoxaline derivatives (Table 2). Thus, the treatment of 1-(2amino-1-phenyl)pyrrole with terminal alkynes gave the quinoxaline products $\mathbf{7}$, in which the a-pyrrole $\mathrm{sp}^{2} \mathrm{C}-\mathrm{H}$ bond has been selectively activated (entries 1-4). Similarly, the coupling products 8 and $\mathbf{9}$ resulted from the regioselective $\mathrm{C}-\mathrm{H}$ bond activation/cyclization of $\mathrm{N}$ (2-aminophenyl)- and 2-(2-aminophenyl)indoles, respectively (entries $5-10)$. Only 1 equiv of terminal alkyne has been regioselectively inserted into the $\mathrm{sp}^{2} \mathrm{C}-\mathrm{H}$ bond to give the cyclic products for these cases. The quinoxaline derivatives have been shown to display a variety of biologically important functions including use as agents for the treatment of tuberculosis. ${ }^{15}$

Table 2. Coupling Reaction of Pyrrole- and Indole-Substituted Aniline and Terminal Alkynes ${ }^{a}$

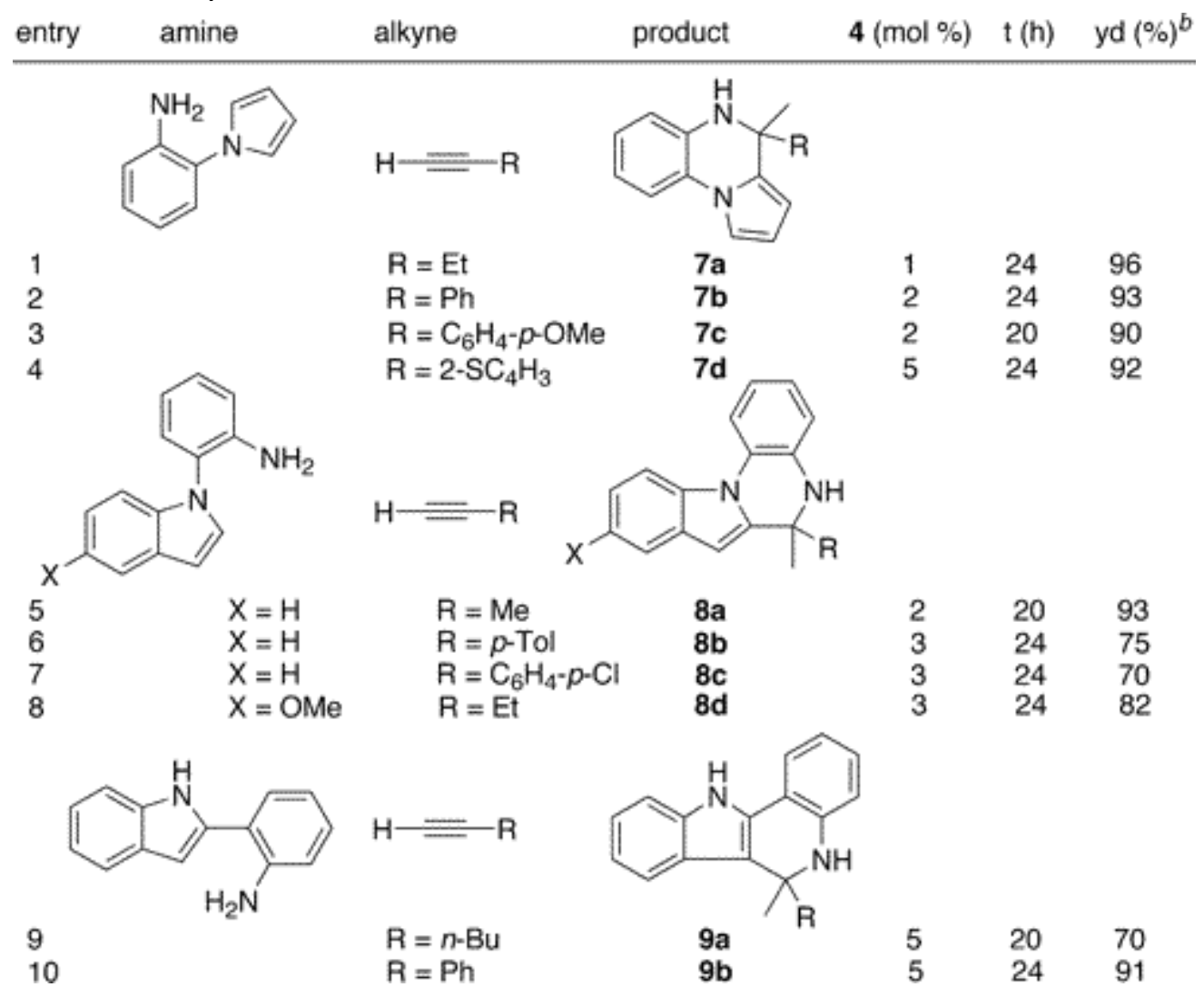

a Reaction conditions: amine $(1.5 \mathrm{mmol})$, alkyne $(2-5 \mathrm{mmol}), \mathrm{Ru}_{3}(\mathrm{CO})_{12} / \mathrm{HBF}_{4} \cdot \mathrm{OEt}_{2}$ (1:3), benzene $(2-5 \mathrm{~mL}), 90-95^{\circ} \mathrm{C} . .^{b}$ Isolated yield based on amine.

Journal of the American Chemical Society, Vol 127, No. 48 (2005): pg. 17000-17006. DOI. This article is (C) American Chemical Society and permission has been granted for this version to appear in e-Publications@Marquette. American Chemical Society does not grant permission for this article to be further copied/distributed or hosted elsewhere without the express permission from American Chemical Society. 
NOT THE PUBLISHED VERSION; this is the author's final, peer-reviewed manuscript. The published version may be accessed by following the link in the citation at the bottom of the page.

Mechanistic Study: Isotope Effect. The mechanism of the catalytic reaction was examined by employing both indoline and acyclic arylamines. First, a normal deuterium isotope effect was observed from the reaction of $\mathrm{C}_{6} \mathrm{H}_{5} \mathrm{NH}_{2}$ and $\mathrm{C}_{6} \mathrm{D}_{5} \mathrm{NH}_{2}$ with propyne. The pseudofirst-order plots of the catalytic reaction of both $\mathrm{C}_{6} \mathrm{H}_{5} \mathrm{NH}_{2}$ and $\mathrm{C}_{6} \mathrm{D}_{5} \mathrm{NH}_{2}$ with propyne at $95^{\circ} \mathrm{C}$ gave $k_{\text {obs }}=9.6 \times 10^{-2} \mathrm{~h}^{-1}$ and $k_{\text {obs }}=3.9 \times 10^{-2}$ $\mathrm{h}^{-1}$, respectively, from which $k_{\mathrm{CH}} / k_{\mathrm{CD}}=2.5 \pm 0.1$ was calculated (Figure S1, Supporting Information). In contrast, analogous reactions of $m-(\mathrm{OMe}) \mathrm{C}_{6} \mathrm{H}_{4} \mathrm{NHCH}_{3}$ and $m-(\mathrm{OMe}) \mathrm{C}_{6} \mathrm{H}_{4} \mathrm{NDCH}_{3}$ with propyne and $m-$ (OMe) $\mathrm{C}_{6} \mathrm{H}_{4} \mathrm{NHCH}_{3}$ with $\mathrm{HC}: \mathrm{CPh}$ and $\mathrm{DC}: \mathrm{CPh}$ at $95^{\circ} \mathrm{C}$ gave negligible isotope effects of $k_{\mathrm{NH}} / k_{\mathrm{ND}}=1.1 \pm 0.1$ and $k_{\mathrm{CH}} / k_{\mathrm{CD}}=1.05 \pm 0.1$, respectively. These results indicate that the arene $\mathrm{C}-\mathrm{H}$ bond activation is the rate-limiting step for the catalytic reaction.

Hammett Study. The electronic effect of the ortho-C-H bond activation was examined for a number of different meta-substituted anilines. The Hammett $\rho=-4.4$ was obtained from the correlation of the relative rates with $\sigma_{\mathrm{p}}$ for a series of meta-substituted anilines, $m$ $\mathrm{XC}_{6} \mathrm{H}_{4} \mathrm{NH}_{2}\left(\mathrm{X}=\mathrm{OMe}, \mathrm{CH}_{3}, \mathrm{H}, \mathrm{F}\right)$, with propyne in the presence of 4/ $\mathrm{HBF}_{4} \cdot \mathrm{OEt}_{2}$ (3 mol \% 4, 1:3 molar ratio) at $95^{\circ} \mathrm{C}$ (Figure 1). Such a highly negative $\rho$ value has been commonly observed in organic substitution reactions involving a carbocation intermediate. ${ }^{16}$ In our case, a highly negative $\rho$ value suggests considerable cationic character on the transition state of the arene $\mathrm{C}-\mathrm{H}$ bond activation step via the formation of ruthenium aryl species. The hydroamination product $\mathbf{6}$ was formed predominantly for the anilines with an electronwithdrawing group (for example, $85 \%$ of $\mathbf{6}$ and $\sim 10 \%$ of 5 for $\mathrm{m}$ $\mathrm{FC}_{6} \mathrm{H}_{4} \mathrm{NH}_{2}$ ), and this may be due to a relatively unfavorable ortho- $\mathrm{C}-\mathrm{H}$ bond activation compared to the hydroamination reaction path. The fact that no correlation was observed between the relative rates of aniline with aryl-substituted alkynes $p-\mathrm{XC}_{6} \mathrm{H}_{4} \mathrm{C}: \mathrm{CH}\left(\mathrm{X}=\mathrm{OMe}, \mathrm{CH}_{3}, \mathrm{Cl}\right.$, $\mathrm{F}$ ) and the Hammett $\sigma_{\mathrm{p}}$ indicates that the alkyne $\mathrm{C}-\mathrm{H}$ bond activation step is not rate-limiting. 


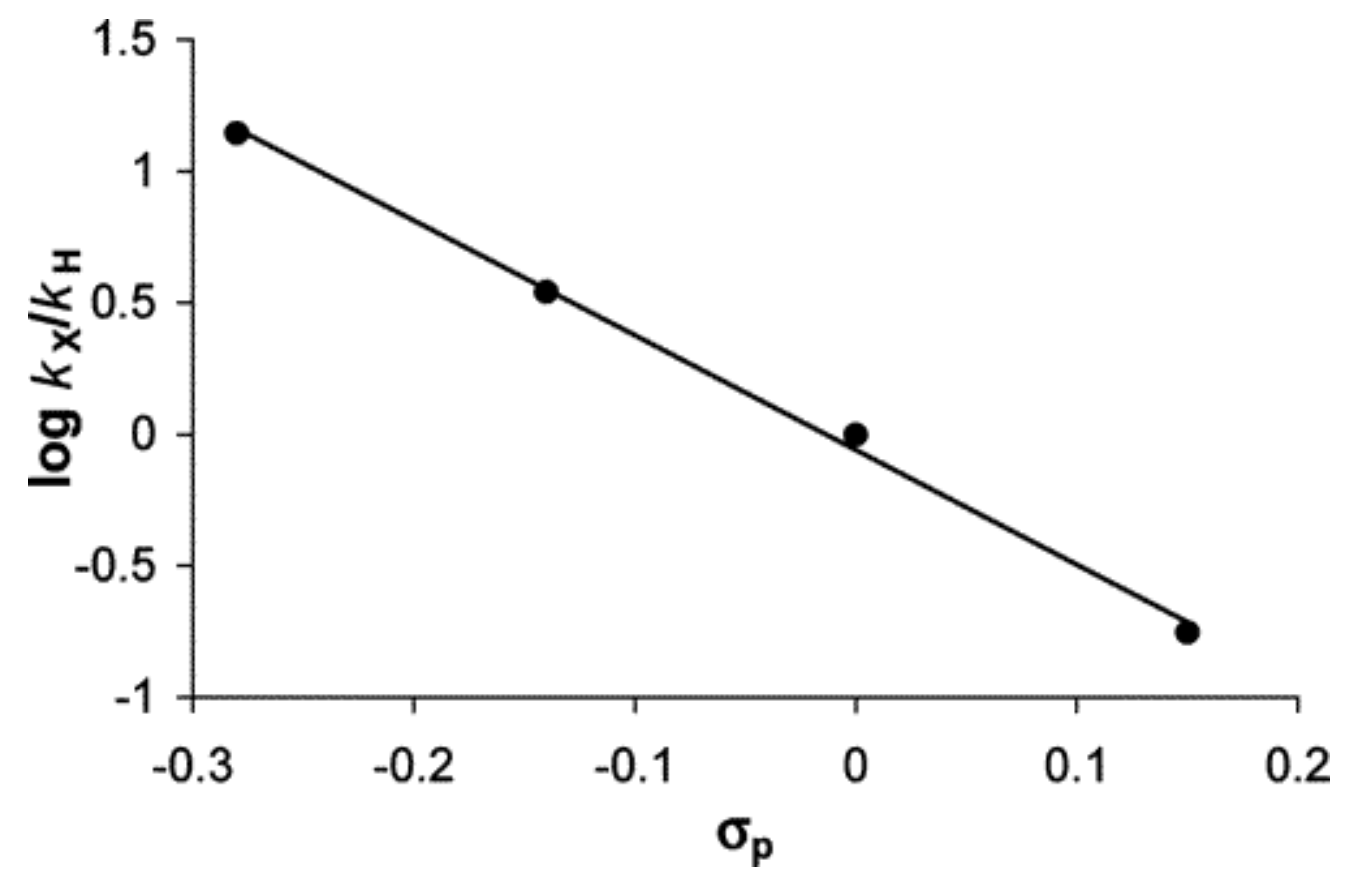

Figure 1 Hammett plot for the coupling reaction of $m-\mathrm{XC}_{6} \mathrm{H}_{4} \mathrm{NH}_{2}\left(\mathrm{X}=\mathrm{OMe}, \mathrm{CH}_{3}, \mathrm{H}, \mathrm{F}\right)$ with $\mathrm{HC}: \mathrm{CCH}_{3}$ using the catalyst $4 / \mathrm{HBF}_{4} \cdot \mathrm{OEt}_{2}$ (3 mol \%, $1: 3$ ratio).

The coupling reaction catalyzed by $\mathbf{1}$ was found to be strongly inhibited by added phosphines. For example, the addition of $5 \mathrm{~mol} \%$ $\mathrm{PC}_{3}$ under the reaction conditions shown in eq 1 led to $<30 \%$ of the product $\mathbf{2 a}$ after $24 \mathrm{~h}$. The pseudo-first-order plots showed that the observed rate constant from the reaction with $5 \mathrm{~mol} \%$ added $\mathrm{PCy}_{3}$ $\left(k_{\text {obs }}=4.9 \times 10^{-2} \mathrm{~h}^{-1}\right)$ was found to be nearly 3 times smaller than the rate under normal conditions ( $k_{\mathrm{obs}}=1.7 \times 10^{-1} \mathrm{~h}^{-1}$ ) (Figure S2, Supporting Information). This result suggests that the reactive species is generated from the reversible dissociation of phosphines for the reactions catalyzed by $\mathbf{1}$.

Deuterium Labeling Study. The reaction of indoline with excess DC: $\mathrm{CPh}$ ( 10 equiv) and $4 / \mathrm{NH}_{4} \mathrm{PF}_{6}(3 \mathrm{~mol} \%$ ) yielded the product 2b with extensive deuterium incorporation on both the vinyl (85\%) and methyl ( $81 \%$ ) positions as well as on the arene hydrogen para to the amine group ( $50 \%$ ) as measured by both ${ }^{1} \mathrm{H}$ and ${ }^{2} \mathrm{H}$ NMR (eq 3 ). Conversely, ca. $25 \%$ of the methyl group and $30 \%$ of the vinyl hydrogen of $\mathbf{2} \mathbf{b}$ were found to contain the deuterium when $\mathrm{N}$ deuterated indoline was reacted with 10 equiv of $\mathrm{HC}: \mathrm{CPh}$. 
NOT THE PUBLISHED VERSION; this is the author's final, peer-reviewed manuscript. The published version may be accessed by following the link in the citation at the bottom of the page.

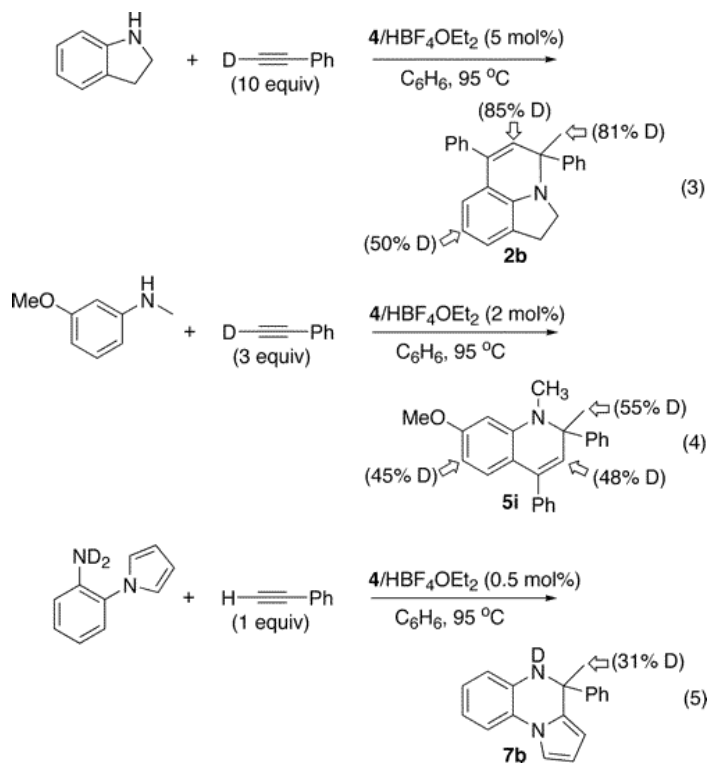

Similar results were obtained from the reactions of acyclic arylamines. For example, the treatment of $m-(\mathrm{OMe}) \mathrm{C}_{6} \mathrm{H}_{4} \mathrm{NHCH}_{3}$ with DC:CPh ( 3 equiv) gave the product $\mathbf{5 i}$ with extensive deuterium incorporation on both the a-methyl (55\%) and vinyl (48\%) as well as on the arene positions ( $45 \%$ combined at $\mathrm{C}_{6}$ and $\mathrm{C}_{8}$ ) (eq 4 ). Lower deuterium incorporation was observed for $\mathbf{5 i}$ compared to $\mathbf{2} \mathbf{b}$, and this may be in part due to the smaller amount of DC:CPh than in eq 3 and the slower reaction rate for an acylic secondary amine, which might have led to $\mathrm{H} / \mathrm{D}$ exchange to other arene positions. Conversely, the reaction of $m$-(OMe) $\mathrm{C}_{6} \mathrm{H}_{4} \mathrm{NDCH}_{3}$ with $\mathrm{HC}: \mathrm{CPh}$ (3 equiv) resulted in $\mathbf{5} \mathbf{i}$ with significant amounts of deuterium on the a-methyl (18\%), vinyl $(10 \%)$, and arene $(11 \%)$ positions. A similar deuterium incorporation pattern was also observed for one-to-one coupling reaction of $\mathrm{N}$ deuterated 1-(2-amino-1-phenyl)pyrrole with $\mathrm{HC}: \mathrm{CPh}$ (1 equiv) (eq 5). In this case, the deuterium was selectively incorporated into the amethyl group ( $31 \%$ ) of $\mathbf{7 b}$ without significant exchange to other arene positions. In a control experiment, the treatment of $m$ (OMe) $\mathrm{C}_{6} \mathrm{H}_{4} \mathrm{NHCH}_{3}$ with DC:CPh (3 equiv) in the presence of $\mathrm{HBF}_{4} \cdot \mathrm{OEt}_{2}$ ( $6 \mathrm{~mol} \%$ ) under otherwise similar conditions led to $<5 \%$ of deuterium exchange to the ortho- and para-arene positions of $\mathrm{m}$ (OMe) $\mathrm{C}_{6} \mathrm{H}_{4} \mathrm{NHCH}_{3}$ after $24 \mathrm{~h}$ of reaction time at $95{ }^{\circ} \mathrm{C}$, without forming any measurable amount of the product $\mathbf{5 i}$. These results indicate that both the $\mathrm{N}-\mathrm{H}$ and the acetylenic $\mathrm{C}-\mathrm{H}$ bond activation steps are reversible. 
Reactions of the Cationic Ruthenium Acetylide Complex. We previously detected the formation of cationic ruthenium acetylide complexes during the catalytic reactions mediated by $\mathbf{1}$. The cationic ruthenium acetylide complex $\left[\left(\mathrm{PCy}_{3}\right)_{2}(\mathrm{CO})\left(\mathrm{CH}_{3} \mathrm{CN}\right)_{2} \mathrm{RuC}: \mathrm{CPh}\right]^{+} \mathrm{BF}_{4}^{-}$

(10a) was subsequently isolated in $81 \%$ yield from the reaction of $\mathbf{1}$ with $\mathrm{HC}: \mathrm{CPh}$ in THF, and its structure was established by X-ray crystallography. ${ }^{11}$ The activity of isolated complex 10a was found to be very similar to that of $\mathbf{1}$ for the catalytic coupling reactions of both indoline and aniline with terminal alkynes. The isolation of the catalytically active complex 10a enabled us to further examine the reactions that are relevant to the catalysis. For example, the treatment of 10a with $\mathrm{HC}: \mathrm{CC}_{6} \mathrm{H}_{4}-p$-OMe (5 equiv) in THF for $3 \mathrm{~h}$ at $80{ }^{\circ} \mathrm{C}$ produced a $\sim 1: 1$ mixture of 10a and the alkyne-exchanged complex $\left[\left(\mathrm{PCy}_{3}\right)_{2}(\mathrm{CO})\left(\mathrm{CH}_{3} \mathrm{CN}\right)_{2} \mathrm{RuC}: \mathrm{CC}_{6} \mathrm{H}_{4}-p-\mathrm{OMe}\right]^{+} \mathrm{BF}_{4}^{-}$(10b) (eq 6). Similarly, the reaction of $10 a$ with indoline (1 equiv) and propyne (10 equiv) was monitored by NMR (eq 7). In this case, only the propyne coupling product $\mathbf{2 a}$ was formed without any observable amount of the phenylsubstituted product $\mathbf{2 - P h}$. Both of these results indicate that the alkyne exchange process is relatively facile under the catalytic reaction conditions.
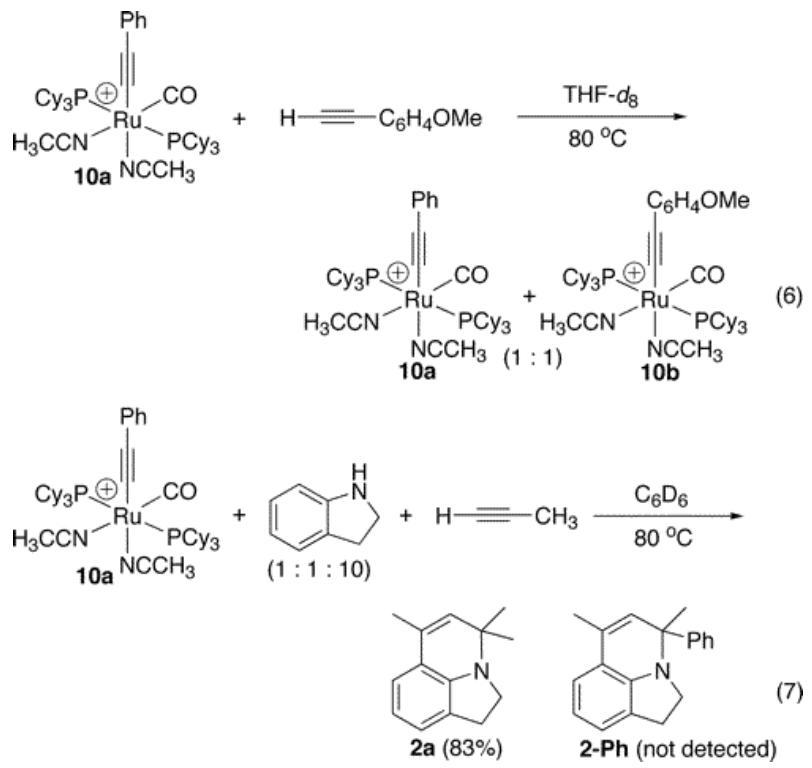


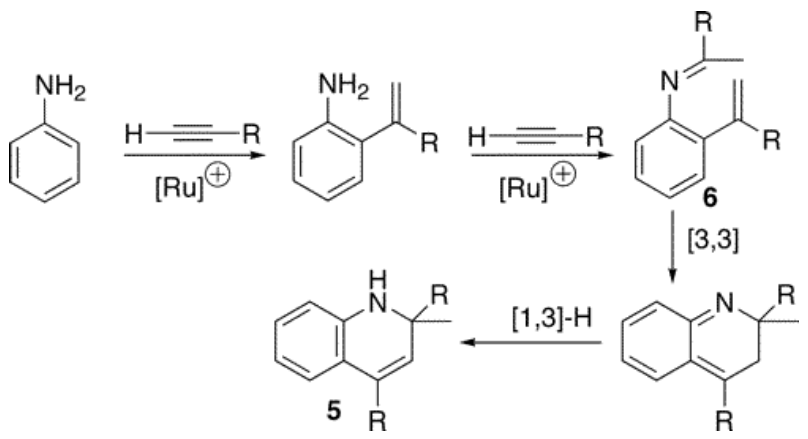

\section{Scheme 1}

Mechanism of the Catalytic Reaction. We initially considered a few different mechanistic pathways to explain the formation of $\mathrm{C}-\mathrm{H}$ bond activation products. One of the possible mechanisms involves sequential ortho- $\mathrm{C}-\mathrm{H}$ bond activation and hydroamination reactions as depicted in Scheme 1. The key features of this mechanism are the ruthenium-mediated ortho- $\mathrm{C}-\mathrm{H}$ bond insertion of an alkyne to form the ortho-vinylated amine, the hydroamination of the second alkyne, and the subsequent electrocyclization to give the product $\mathbf{5}$. Both hydroamination of alkynes and ortho- $\mathrm{C}-\mathrm{H}$ bond insertion of arylamines have been well-documented in the literature. ${ }^{1,17}$

We reasoned that the reaction of independently prepared 2vinylaniline with terminal alkynes would result in the product $\mathbf{5}$ under similar catalytic conditions if 2-vinylaniline were an intermediate for the catalytic reaction. We tested this hypothesis by examining the reaction of 2-isopropenylaniline with terminal alkynes (Scheme 2). The hydroamination product 6-Ph was exclusively produced from the reaction of 2-isopropenylaniline with phenylacetylene under the catalytic conditions, and moreover, 6-Ph was not converted to the cyclized product 5-Ph even after prolonged heating at $95^{\circ} \mathrm{C}$ for $48 \mathrm{~h}$. In a separate experiment, the treatment of the independently formed hydroamination product $\mathbf{6} \mathbf{b}$ with excess propyne did not give the cyclized product 5-Ph. Though the reaction of independently generated 2-isopropenylaniline with excess propyne resulted in a mixture of products $\mathbf{5 a}$ and $\mathbf{6 - M e}(40: 60)$, the hydroamination product 6-Me was not converted to the cyclized product 5a under the reaction conditions. The treatment of $\mathbf{6 a}$ with excess propyne did not give the product 5a either. The similar [3,3]-electrocyclic reactions are often conducted under strongly acidic conditions at elevated temperature, ${ }^{18}$ 
and we believe that $\mathrm{HBF}_{4}$ might have acted as an acid catalyst in forming the cyclization product $\mathbf{5 a}$ in the case of propyne. Since the formation of hydroamination product $\mathbf{6}$ is generally much favored over that of the ortho- $\mathrm{C}-\mathrm{H}$ bond insertion product $\mathbf{5}$ for the reaction of arylamines with alkynes and $\mathbf{6}$ does not convert to the cyclized product 5, 2-isopropenylaniline cannot be a viable intermediate for the catalytic reaction. Uchimaru also reported that the reaction of arylamines with alkynes predominantly formed the hydroamination product over the ortho- $\mathrm{C}-\mathrm{H}$ bond activation product. ${ }^{13 \mathrm{~b}}$ Taking these results together, we ruled out the sequential mechanism of orthovinylation and hydroamination of alkynes for the catalytic reaction.

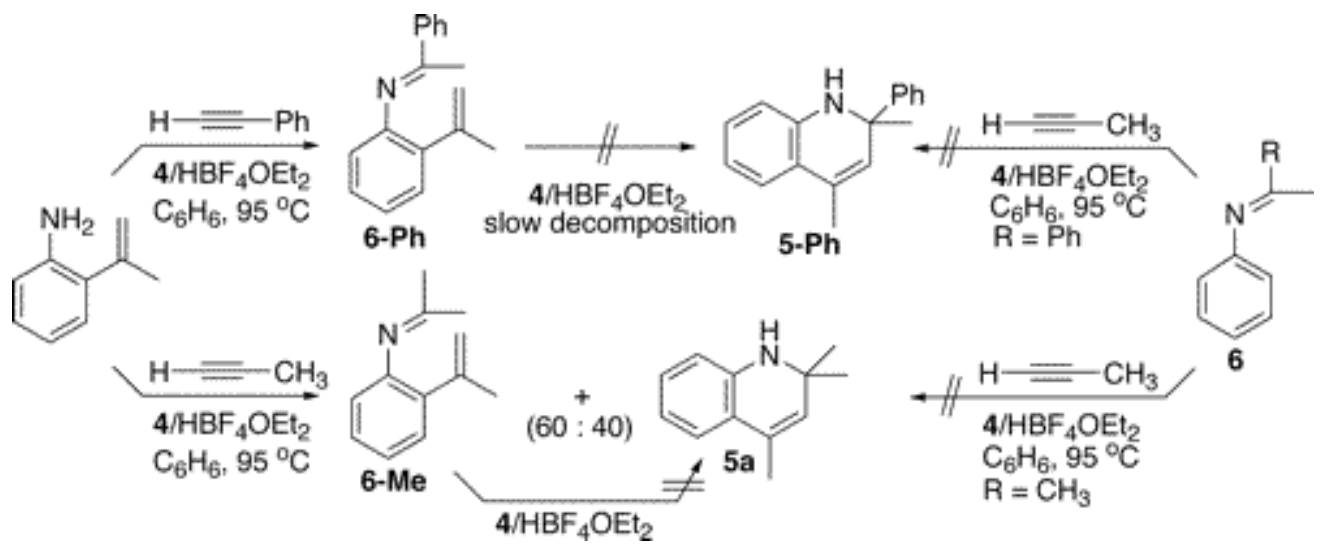

Scheme 2

The observed data are consistent with a mechanism involving an unsaturated cationic ruthenium acetylide complex, 10, as the key species (Scheme 3 ). We previously showed that the catalytically active acetylide species $\mathbf{1 0 a}$ is generated during the reactions catalyzed by the cationic hydride complex $\mathbf{1}$. Two possible mechanistic pathways can be considered for the $\mathrm{C}-\mathrm{N}$ bond forming step from 10, an intermolecular nucleophilic addition vs an intramolecular migratory insertion mechanism (Scheme 4), both of which would lead to the cationic enaminyl species $\mathbf{1 1}$. The subsequent ortho-arene $\mathrm{C}-\mathrm{H}$ bond activation and the reductive elimination of the vinyl group would form the ortho-metalated species $\mathbf{1 2}$. The extensive deuterium incorporation into aryl positions on the product $\mathbf{5}$ can be rationalized by the formation of ortho- and para-metalated species from reversible arene $\mathrm{C}-\mathrm{H}$ bond activation steps, from which the ortho-metalated species would lead to product formation. Furthermore, the results from the deuterium labeling studies indicate that the arene $\mathrm{C}-\mathrm{H}$ bond 
activation step is reversible as shown in Scheme 3. Both the normal isotope effect of $k_{\mathrm{CH}} / k_{\mathrm{CD}}$ and a highly negative Hammett $\rho$ value are consistent with the arene $\mathrm{C}-\mathrm{H}$ bond activation rate-limiting step. The negative $\rho$ value also suggests the formation of cationic ruthenium aryl species during the arene ortho- $\mathrm{C}-\mathrm{H}$ bond activation step. The second alkyne insertion and the regioselective migratory insertion/cyclization steps would yield the cationic alkyl species 13. Since $\mathbf{1 3}$ does not have any $\beta$-hydrogens, either the oxidative addition/reductive elimination or the $\sigma$-bond metathesis of the terminal alkyne must be invoked for the formation of $\mathbf{5}$ and the regeneration of the acetylide complex $\mathbf{1 0}$. For arylamines with a meta-electron-withdrawing group, the predominant formation of hydroamination product $\mathbf{6}$ can be readily rationalized by the preferential oxidative addition/reductive elimination of another terminal alkyne from $\mathbf{1 1}$. Site-selective $\mathrm{C}-\mathrm{H}$ activation and functionalization reactions by trimetallic $\mathrm{Ru}_{3}(\mathrm{CO})_{12}$ have been observed for a number of different catalytic reactions. ${ }^{19}$

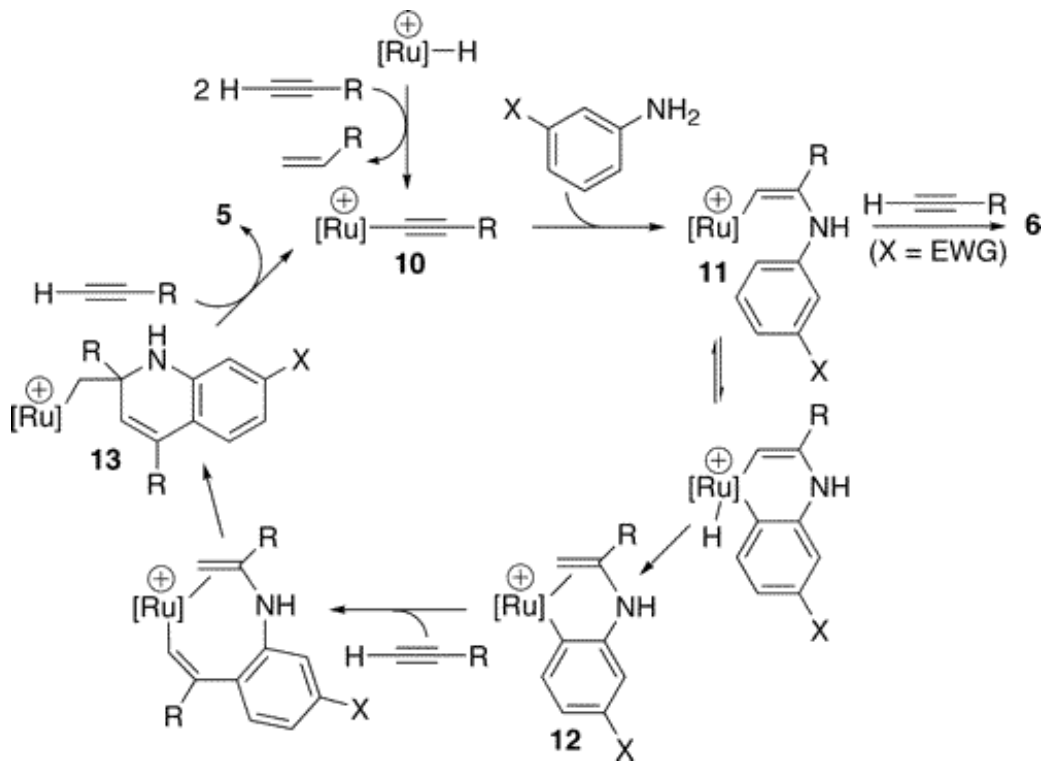

Scheme 3 
Path A. Intermolecular nucleophilic addition of amine.

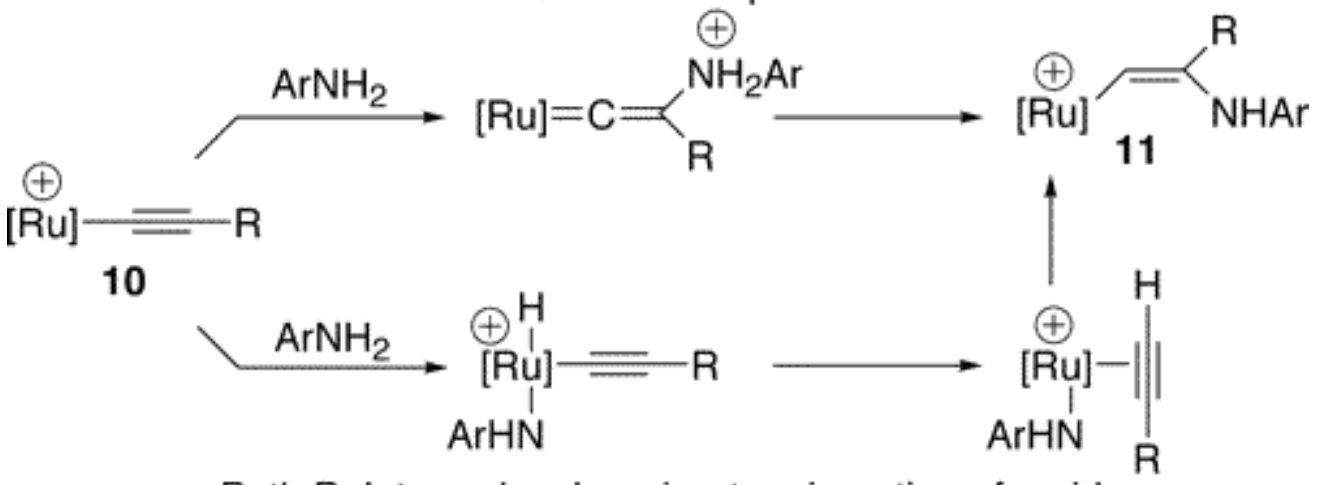

Scheme 4

Path B. Intramolecular migratory insertion of amide.

Two different pathways have been commonly proposed for the hydroamination reactions. For example, Hartwig provided strong evidence for an intermolecular nucleophilic addition mechanism for the Pd-catalyzed hydroamination of aryl-substituted alkenes. ${ }^{20}$ Both concerted and stepwise intramolecular migratory insertion mechanisms via metal amido complexes have been commonly proposed for earlytransition- and lanthanide-metal-mediated hydroamination reactions. ${ }^{21}$ In our case, intermolecular nucleophilic addition of amine to the $\beta$ acetylide carbon and the subsequent proton transfer would form the enaminyl intermediate $\mathbf{1 1}$ (Scheme 4, path A). Alternatively, the formation of an alkyne-coordinated amido complex (from initial $\mathrm{N}-\mathrm{H}$ bond activation and the hydrogen transfer to the acetylide ligand) and the intramolecular migratory insertion of the amido group should lead to the same enaminyl intermediate $\mathbf{1 1}$ (path B).

We envisioned a crossover experiment to probe between interand intramolecular mechanistic pathways for the $\mathrm{C}-\mathrm{N}$ bond forming step (Scheme S1, Supporting Information). We reasoned that the amount of deuterium atoms at the a-methyl positions in the reaction of an arylamine with a $1: 1$ mixture of $\mathrm{DC}: \mathrm{CPh}$ and $\mathrm{HC}: \mathrm{CC}_{6} \mathrm{H}_{4}-p-\mathrm{OMe}$ would be significantly different for the inter- vs intramolecular mechanisms. According to the intermolecular nucleophilic addition mechanism, an equal amount of deuterium (17\%) is expected to be incorporated into both a- $\mathrm{CH}_{3}$ groups of the products from the statistical $\mathrm{H} / \mathrm{D}$ distribution of the alkyne $\mathrm{C}-\mathrm{H}$ bond to the products (Scheme S1, path A). The sequential mechanism as described in Scheme 1 would also result in a similar deuterium incorporation 
pattern. In contrast, the intramolecular migratory insertion mechanism is expected to give products with a substantially higher deuterium incorporation into the a- $\mathrm{CH}_{3}$ of the phenyl-substituted product (50\%) compared to that of the $p$-(OMe) $\mathrm{C}_{6} \mathrm{H}_{4}$-substituted product $(17 \%)$, if one assumes a rapid and reversible alkyne substrate exchange and the subsequent statistical $\mathrm{H} / \mathrm{D}$ distribution from the alkyne $\mathrm{C}-\mathrm{H}$ bond oxidation/reductive elimination steps (Scheme S1, path B).

An initial reaction survey for both indoline and meta-substituted aniline with a mixture of two different alkynes produced a complex mixture of both homocoupling and cross-coupling products. To simplify the product analysis, pyrrole-substituted aniline was employed since it incorporates only 1 equiv of terminal alkyne per molecule of amine. Thus, the treatment of 1-(2-aminophenyl)pyrrole $(1.9 \mathrm{mmol})$ with a $1: 1$ mixture of $\mathrm{DC}: \mathrm{CPh}$ and $\mathrm{HC}: \mathrm{CC}_{6} \mathrm{H}_{4}-p$-OMe (1 equiv each) in the presence of the catalyst $4 / \mathrm{HBF}_{4} \cdot \mathrm{OEt}_{2}(1 \mathrm{~mol} \%)$ at $95{ }^{\circ} \mathrm{C}$ in benzene solution produced $\mathrm{a} \sim 1: 1$ mixture of $\mathbf{7 b}-d$ and $7 \mathbf{c}-d$ after $24 \mathrm{~h}$ (eq 8 ). The products were separated by simple column chromatography on silica gel, and the deuterium content of the products was analyzed by both ${ }^{1} \mathrm{H}$ and ${ }^{2} \mathrm{H}$ NMR. The NMR analysis clearly showed substantially higher deuterium incorporation into the $\mathbf{a}-\mathrm{CH}_{3}$ group of $\mathbf{7 b} \mathbf{b}-d(48 \%)$ compared to that of $\mathbf{7 c - d}(15 \%)$. In a control experiment, the reaction in the absence of the ruthenium catalyst 4 neither resulted in any significant $\mathrm{H} / \mathrm{D}$ exchange between $\mathrm{DC}: \mathrm{CPh}$ and $\mathrm{HC}: \mathrm{CC}_{6} \mathrm{H}_{4}-p-\mathrm{OMe}$ nor gave any measurable products 7 . Thus, the observed deuterium incorporation pattern must have occurred during the catalytic reaction and provides strong evidence for the intramolecular migratory insertion mechanism.

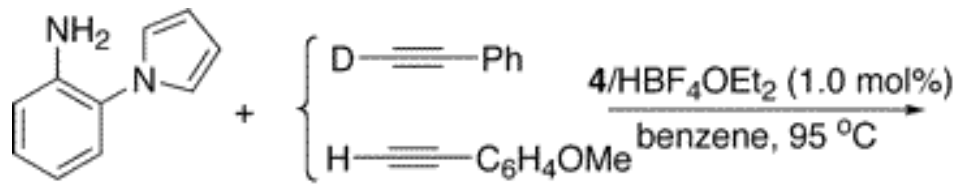

$(1: 1)$

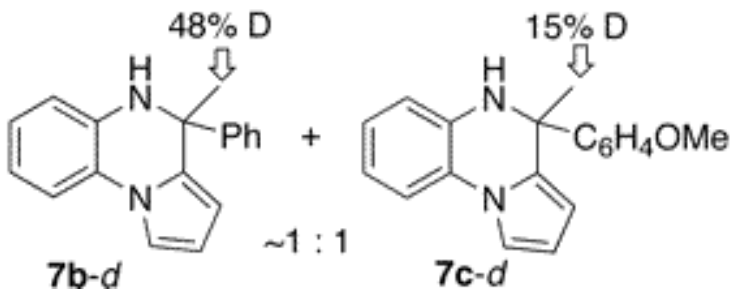


NOT THE PUBLISHED VERSION; this is the author's final, peer-reviewed manuscript. The published version may be accessed by following the link in the citation at the bottom of the page.

\section{Conclusion}

A new catalytic $\mathrm{C}-\mathrm{H}$ bond activation/cyclization protocol has been developed for the synthesis for quinoline and quinoxaline derivatives. The mechanistic data are consistent with the mechanism involving an intramolecular migratory insertion of amine and the subsequent ortho- $\mathrm{C}-\mathrm{H}$ bond activation and cyclization via an unsaturated cationic ruthenium acetylide complex. The catalytic $\mathrm{C}-\mathrm{H}$ bond activation/cyclization method should find a range of new applications for the synthesis of quinoline and other nitrogen heterocyclic compounds.

\section{Experimental Section}

General Information. All operations were carried out in a nitrogen-filled glovebox or by using standard high-vacuum and Schlenk techniques unless otherwise noted. Tetrahydrofuran, benzene, hexanes, and $\mathrm{Et}_{2} \mathrm{O}$ were distilled from purple solutions of sodium and benzophenone immediately prior to use. The NMR solvents were dried from activated molecular sieves $(4 \AA)$. All amine and alkyne substrates were received from commercial sources and used without further purification. $\mathrm{RuCl}_{3} \cdot 3 \mathrm{H}_{2} \mathrm{O}$ and $\mathrm{Ru}_{3}(\mathrm{CO})_{12}$ were obtained from commercial sources, and complex $\mathbf{1}$ was prepared by following a reported procedure. ${ }^{22}$ The ${ }^{1} \mathrm{H},{ }^{13} \mathrm{C}$, and ${ }^{31} \mathrm{P}$ NMR spectra were recorded on a Varian Mercury $300 \mathrm{MHz}$ FT-NMR spectrometer. Mass spectra were recorded from a Hewlett-Packard HP 5970 GC/MS spectrometer. Highresolution FAB mass spectra were obtained at the Center of Mass Spectrometry, Washington University, St. Louis, MO. Elemental analyses were performed at the Midwest Microlab, Indianapolis, IN.

Isotope Effect Study. In a glovebox, equal amounts of $\mathrm{C}_{6} \mathrm{H}_{5} \mathrm{NH}_{2}$ and $\mathrm{C}_{6} \mathrm{D}_{5} \mathrm{NH}_{2}(0.4 \mathrm{mmol}, 37 \mu \mathrm{L})$ were added via a syringe to two separate $25 \mathrm{~mL}$ Schlenk tubes. Predissolved $\mathrm{Ru}_{3}(\mathrm{CO})_{12}(8 \mathrm{mg}, 3$ $\mathrm{mol} \%$ ) in benzene solution ( $3 \mathrm{~mL}$ ) was added to each Schlenk tube. The reaction tubes were brought out of the box, and $\mathrm{HBF}_{4} \cdot \mathrm{OEt}_{2}(8 \mu \mathrm{L}$, $9 \mathrm{~mol} \%$ based on amine) was added to each tube under a nitrogen stream. The reaction tubes were cooled in a liquid nitrogen bath, and excess propyne $(2 \mathrm{mmol})$ was condensed into each tube via a vacuum line transfer. The reaction tubes were warmed to room temperature 
and stirred in an oil bath at $95^{\circ} \mathrm{C}$. A small portion of the aliquot under a nitrogen stream was drawn periodically from the reaction tube, and the product conversion was determined by GC.

Hammett Study. In a glovebox, meta-substituted aniline $\mathrm{m}$ $\mathrm{XC}_{6} \mathrm{H}_{4} \mathrm{NH}_{2}\left(\mathrm{X}=\mathrm{OMe}, \mathrm{CH}_{3}, \mathrm{H}, \mathrm{F}\right)(0.54 \mathrm{mmol}), \mathrm{Ru}_{3}(\mathrm{CO})_{12}(10 \mathrm{mg}, 0.016$ $\mathrm{mmol})$, and benzene ( $3 \mathrm{~mL}$ ) were added to each of four separate 25 $\mathrm{mL}$ Schlenk tubes equipped with a stirring bar. The reaction tubes were brought out of the box, and $\mathrm{HBF}_{4} \cdot \mathrm{OEt}_{2}(10 \mu \mathrm{L}, 9 \mathrm{~mol} \%$ based on amine) was added to each tube under a nitrogen stream. The reaction tubes were cooled in a liquid nitrogen bath, and excess propyne ( 2 mmol) was condensed into each tube via a vacuum line transfer. The reaction tubes were warmed to room temperature and stirred in an oil bath at $95^{\circ} \mathrm{C}$. A small portion of the aliquot under a nitrogen stream was drawn periodically from each reaction tube. $k_{\text {obs }}$ was determined from a first-order plot of In [5] vs time as measured by the appearance of the product $\mathbf{5}$ by GC.

Representative Procedure of Deuterium Labeling Study: Reaction of $\mathbf{m}-(\mathrm{OMe}) \mathbf{C}_{6} \mathbf{H}_{4} \mathbf{N H C H}_{3}$ with $\mathbf{D C} \equiv \mathbf{C P h}$. In a glovebox, $\mathrm{m}$ (OMe) $\mathrm{C}_{6} \mathrm{H}_{4} \mathrm{NHCH}_{3}(300 \mathrm{mg}, 2.2 \mathrm{mmol})$, DC:CPh (676 mg, $\left.6.6 \mathrm{mmol}\right)$, and $\mathrm{Ru}_{3}(\mathrm{CO})_{12}(28 \mathrm{mg}, 43 \mu \mathrm{mol})$ were dissolved in $5 \mathrm{~mL}$ of benzene in a $25 \mathrm{~mL}$ Schlenk tube equipped with a magnetic stirring bar. The reaction tube was brought out of the box, and $\mathrm{HBF}_{4} \cdot \mathrm{OEt}_{2}(28 \mu \mathrm{L}, 3$ equiv based on Ru) was added via a microsyringe under a stream of nitrogen. The reaction tube was stirred in an oil bath at $95^{\circ} \mathrm{C}$ for $24 \mathrm{~h}$. The solvent was removed from a rotary evaporator, and the organic product was isolated by column chromatography on silica gel (hexane: $\mathrm{CH}_{2} \mathrm{Cl}_{2}=3: 2$ ). The deuterium content of the product $5 \mathbf{i}$ was measured by both ${ }^{1} \mathrm{H} \mathrm{NMR}\left(\mathrm{CDCl}_{3}\right.$ and cyclohexane $(10 \mathrm{mg}$, external standard)) and ${ }^{2} \mathrm{H} \mathrm{NMR}\left(\mathrm{CH}_{2} \mathrm{Cl}_{2}\right.$ and $\left.\mathrm{CDCl}_{3}(0.05 \mathrm{~mL})\right)$.

Crossover Experiment. In a glovebox, 1-(2aminophenyl)pyrrole (300 mg, $1.9 \mathrm{mmol}$ ), DC:CPh (196 mg, 1.9 $\mathrm{mmol}$ ), $\mathrm{HC}: \mathrm{CC}_{6} \mathrm{H}_{4}-p-O M e\left(250 \mathrm{mg}, 1.9 \mathrm{mmol}\right.$ ), and $\mathrm{Ru}_{3}(\mathrm{CO})_{12}$ (12 mg, $0.019 \mathrm{mmol}$ ) were dissolved in $5 \mathrm{~mL}$ of benzene in a thick-walled 25 $\mathrm{mL}$ Schlenk tube equipped with a magnetic stirring bar. The reaction tube was brought out of the box, and $\mathrm{HBF}_{4} \cdot \mathrm{OEt}_{2}$ ( 3 equiv based on ruthenium) was added via a microsyringe under a stream of nitrogen. 
The reaction tube was stirred in an oil bath at $95^{\circ} \mathrm{C}$ for $24 \mathrm{~h}$. The solvent was removed from a rotary aspirator, and the organic products 7b and 7c were isolated by column chromatography on silica gel (hexane: $\mathrm{CH}_{2} \mathrm{Cl}_{2}=1: 1$ ). The deuterium content of each product was measured by both ${ }^{1} \mathrm{H} \mathrm{NMR}\left(\mathrm{CDCl}_{3}\right.$ and cyclohexane as an external standard) and ${ }^{2} \mathrm{H}$ NMR $\left(\mathrm{CH}_{2} \mathrm{Cl}_{2}\right.$ and $0.05 \mathrm{~mL}$ of $\left.\mathrm{CDCl}_{3}\right)$.

Phosphine Inhibition Study. In a glovebox, complex 1 (36 $\mathrm{mg}, 5 \mathrm{~mol} \%), \mathrm{PCу}_{3}(12 \mathrm{mg}, 5 \mathrm{~mol} \%)$, and indoline (100 mg, 0.8 $\mathrm{mmol}$ ) were dissolved in $5 \mathrm{~mL}$ of benzene in a thick-walled $25 \mathrm{~mL}$ Schlenk tube equipped with a magnetic stirring bar. The reaction tube was brought out of the box and cooled in a liquid nitrogen bath. Excess propyne $(20 \mathrm{mmol})$ was condensed into the tube via a vacuum line transfer. The reaction tube was warmed to room temperature and stirred in an oil bath at $95^{\circ} \mathrm{C}$. A small portion of the aliquot was drawn periodically from the reaction mixture under a nitrogen stream, and the product conversion was determined by GC.

General Procedure of the Catalytic Reaction. In a glovebox, an amine (1-2 mmol), a terminal alkyne (5-10 mmol), and $\mathrm{Ru}_{3}(\mathrm{CO})_{12}$ (10-50 $\mathrm{mg}, 1-5 \mathrm{~mol} \%$ ) were dissolved in $5 \mathrm{~mL}$ of benzene in a thickwalled $25 \mathrm{~mL}$ Schlenk tube equipped with a magnetic stirring bar. The reaction tube was brought out of the box, and $\mathrm{HBF}_{4} \cdot \mathrm{OEt}_{2}(10-50 \mu \mathrm{L}, 3$ equiv based on $\mathrm{Ru}$ ) was added via a microsyringe under a stream of nitrogen. The vacuum-line technique was used to transfer volatile alkynes such as propyne and 1-butyne. The reaction tube was stirred in an oil bath at $95^{\circ} \mathrm{C}$ for $16-24 \mathrm{~h}$. The tube was opened to air at room temperature, and the crude product mixture was analyzed by GC. The solvent was removed from a rotary evaporator, and the organic product was isolated by column chromatography on silica gel (hexane/ $\mathrm{CH}_{2} \mathrm{Cl}_{2}$ ).

\section{Acknowledgment}

Financial support from the National Institutes of Health, General Medical Sciences (Grant R15 GM55987), is gratefully acknowledged. 
NOT THE PUBLISHED VERSION; this is the author's final, peer-reviewed manuscript. The published version may be accessed by following the link in the citation at the bottom of the page.

\section{Supporting Information Available}

Spectroscopic data of organic compounds. This material is available free of charge via the Internet at http//:pubs.acs.org.

\section{References}

${ }^{1}$ Recent reviews: (a) Kakiuchi, F.; Murai, S. In Activation of Unreactive Bonds and Organic Synthesis; Murai, S. Ed.; Springer: New York, 1999. (b) Jia, C.; Kitamura, T.; Fujiwara, Y. Acc. Chem. Res. 2001, 34, 633. (c) Ritleng, V.; Sirlin, C.; Pfeffer, M. Chem. Rev. 2002, 102, 1731.

${ }^{2}$ (a) Tan, K. L.; Bergman, R. G.; Ellman, J. A. J. Am. Chem. Soc. 2001, 123, 2685. (b) Thalji, R. K.; Ahrendt, K. A.; Bergman, R. G.; Ellman, J. A. J. Am. Chem. Soc. 2001, 123, 9692.

${ }^{3}$ (a) Zhang, X.; Fried, A.; Knapp, S.; Goldman, A. S. Chem. Commun. 2003, 2060. (b) Kakiuchi, F.; Tsuchiya, K.; Matsumoto, M.; Mizushima, E.; Chatani, N. J. Am. Chem. Soc. 2004, 126, 12792. (c) Sezen, B.; Sames, D. J. Am. Chem. Soc. 2005, 127, 5284. (d) Zhang, X.; Emge, T. J.; Ghosh, R.; Goldman, A. S. J. Am. Chem. Soc. 2005, 127, 8250.

${ }^{4}$ (a) Chatani, N.; Asaumi, T.; Yorimitsu, S.; Ikeda, T.; Kakiuchi, F.; Murai, S. J. Am. Chem. Soc. 2001, 123, 10935. (b) Kakiuchi, F.; Murai, S. Acc. Chem. Res. 2002, 35, 826.

${ }^{5}$ (a) Dangel, B. D.; Godula, K.; Youn, S. W.; Sezen, B.; Sames, D. J. Am. Chem. Soc. 2002, 124, 11856. (b) Sezen, B.; Franz, R.; Sames, D. J. Am. Chem. Soc. 2002, 124, 13372.

${ }^{6}$ (a) Sezen, B.; Sames, D. J. Am. Chem. Soc. 2004, 126, 13244. (b) Dick, A. R.; Hull, K. L.; Sanford, M. S. J. Am. Chem. Soc. 2004, 126, 2300. (c) Li, Z.; Li, C.-J. J. Am. Chem. Soc. 2005, 127, 6968. (d) Kalyani, D.; Deprez, N. R.; Desai, L. V.; Sanford, M. S. J. Am. Chem. Soc. 2005, 127, 7330. (e) Daugulis, O.; Zaitsev, V. G. Angew. Chem., Int. Ed. 2005, 44, 4046.

${ }^{7}$ (a) Ferreira, E. M.; Stoltz, B. M. J. Am. Chem. Soc. 2003, 125, 9578. (b) Campo, M. A.; Huang, Q.; Yao, T.; Tian, Q.; Larock, R. C. J. Am. Chem. Soc. 2003, 125, 11506. (c) Liu, C.; Han, X.; Wang, X.; Widenhoefer, R. A. J. Am. Chem. Soc. 2004, 126, 3700. (d) DeBoef, B.; Pastine, S. J.; Sames, D. J. Am. Chem. Soc. 2004, 126, 6556. (e) Liu, C.; Widenhoefer, R. A. J. Am. Chem. Soc. 2004, 126, 10250.

${ }^{8}$ (a) Espino, C. G.; Fiori, K. W.; Kim, M.; Du Bois, J. J. Am. Chem. Soc. 2004, 126, 15378. (b) Davies, H. M. L.; Long, M. S. Angew. Chem., Int. Ed. 2005, 44, 3518.

${ }^{9}$ (a) Nobis, M.; Driessen-Hölscher, B. Angew. Chem., Int. Ed. 2001, 40, 3938. (b) Fulton, J. R.; Holland, A. W.; Fox, D. J.; Bergman, R. G. Acc. Chem. Res. 2002, 35, 137. (c) Fulton, J. R.; Sklenak, S.; Bouwkamp, 
M. W.; Bergman, R. G. J. Am. Chem. Soc. 2002, 124, 4722. (d)

Conner, D.; Jayaprakash, K. N.; Cundari, T. R.; Gunnoe, T. B.

Organometallics 2004, 23, 2724.

${ }^{10}$ (a) Yi, C. S.; Yun, S. Y.; He, Z.. Organometallics 2003, 22, 3031. (b) Yi, C.

S.; Yun, S. Y.; Guzei, I. A. Organometallics 2004, 23, 5392. (c) Yi, C.

S.; Yun, S. Y. Org. Lett. 2005, 7, 2181.

${ }^{11} Y i$, C. S.; Yun, S. Y.; Guzei, I. A. J. Am. Chem. Soc. 2005, 127, 5782.

${ }^{12}$ See the Supporting Information (Table S1) for a representative example.

${ }^{13}$ (a) Tokunaga, M.; Eckert, M.; Wakatsuki, Y. Angew. Chem., Int. Ed. 1999, 38, 3222. (b) Uchimaru, Y. Chem. Commun. 1999, 1133.

${ }^{14}$ Selected recent examples: (a) Myers, A. G.; Tom, N. J.; Fraley, M. E.; Cohen, S. B.; Madar, D. J. J. Am. Chem. Soc. 1997, 119, 6072. (b) Takamura, M.; Funabashi, K.; Kanai, M.; Shibasaki, M. J. Am. Chem. Soc. 2001, 123, 6801. (c) Ku, Y.-Y.; Grieme, T.; Raje, P.; Sharma, P.; King, S. A.; Morton, H. E. J. Am. Chem. Soc. 2002, 124, 4282. (d) Ori, M.; Toda, N.; Takami, K.; Tago, K.; Kogen, H. Angew. Chem., Int. Ed. 2003, 42, 2540. (e) Back, T. G.; Wulff, J. E. Angew. Chem., Int. Ed. 2004, 43, 6493.

${ }^{15}$ (a) Seitz, L. E.; Suling, W. J.; Reynolds, R. C. J. Med. Chem. 2002, 45, 5604. (b) Nair, V.; Dhanya, R.; Rajesh, C.; Bhadbhade, M. M.; Manoj, K. Org. Lett. 2004, 6, 4743. (c) Chen, B.-C.; Zhao, R.; Bednarz, M. S.; Wang, B.; Sundeen, J. E.; Barrish, J. C. J. Org. Chem. 2004, 69, 977. (d) Jaso, A.; Zarranz, B.; Aldana, I.; Monge, A. J. Med. Chem. 2005, 48, 2019.

${ }^{16}$ Carey, F. A.; Sundberg, R. J. Advanced Organic Chemistry Part A: Structure and Mechanism, 3rd ed.; Plenum Press: New York, 1990.

${ }^{17}$ (a) Brunet, J. J.; Neibecker, D. In Catalytic Heterofunctionalization from Hydroamination to Hydrozirconation; Togni, A., Grützmacher, H., Eds.; Wiley-VCH: New York, 2001. (b) Roesky, P. W.; Müller, T. E. Angew. Chem., Int. Ed. 2003, 42, 2708.

${ }^{18}$ (a) Hiemstra, H.; Speckamp, W. W. N. In Comprehensive Organic Synthesis; Trost, B. M., Fleming, I., Eds.; Pergamon: New York, 1990; Vol. 5, Chapter 4.5. (b) Cook, G. R.; Barta, N. S.; Stille, J. R. J. Org. Chem. 1992, 57, 461. (c) Shiraishi, K.; Rajca, A.; Pink, M.; Rajca, S. J. Am. Chem. Soc. 2005, 127, 9312.

${ }^{19}$ (a) Fukuyama, T.; Chatani, N.; Tatsumi, J.; Kakiuchi, F.; Murai, S. J. Am. Chem. Soc. 1998, 120, 11522. (b) Godula, K.; Sezen, B.; Sames, D. J. Am. Chem. Soc. 2005, 127, 3648.

${ }^{20}$ (a) Löber, O.; Kawatsura, M.; Hartwig, J. F. J. Am. Chem. Soc. 2001, 123, 4366. (b) Nettekoven, U.; Hartwig, J. F. J. Am. Chem. Soc. 2002, 124, 1166. (c) Hartwig, J. F. Pure Appl. Chem. 2004, 76, 507.

${ }^{21}$ (a) Tian, S.; Arredondo, V. M.; Stern, C. L.; Marks, T. J. Organometallics 1999, 18, 2568. (b) Hong, S.; Tian, S.; Metz, M. V.; Marks, T. J. J. 
NOT THE PUBLISHED VERSION; this is the author's final, peer-reviewed manuscript. The published version may be accessed by following the link in the citation at the bottom of the page.

Am. Chem. Soc. 2003, 125, 14768. (c) Ryu, J.-S.; Li, G. Y.; Marks, T. J. J. Am. Chem. Soc. 2003, 125, 12584.

${ }^{22} Y$ i, C. S.; He, Z.; Guzei, I. A. Organometallics 2001, 20, 3641.

Journal of the American Chemical Society, Vol 127, No. 48 (2005): pg. 17000-17006. DOI. This article is @ American Chemical Society and permission has been granted for this version to appear in e-Publications@Marquette. American Chemical Society does not grant permission for this article to be further copied/distributed or hosted elsewhere without the express permission from American Chemical Society. 